\title{
Sistem Informasi Geografis Wisata Bahari pada Dinas Pariwisata Kota Ternate
}

\author{
Darman Umagapi ${ }^{1}$, Arisandy Ambarita ${ }^{2}$ \\ Program Studi Manajemen Informatika \\ Politeknik Sains dan Teknologi Wiratama Maluku Utara \\ umagapie01@yahoo.com
}

\begin{abstract}
Abstrak
Pariwisata merupakan salah satu sektor unggulan dalam pembangunan untuk meningkatkan pendapatan nasional, penyerapan tenaga kerja, dan penyumbang devisa negara. Penelitian ini betujuan untuk merancang sistem informasi geografis objek wisata bahari pada Dinas Pariwisata Kota Ternate. Metode Analisis dan Pengembangan Sistem menggunakan model terstruktur, serta Pengembangannya menggunakan metode sekuensial linier (Waterfall). Sistem ini dirancang dengan Alat bantu Flowchart, DFD, ERD dan dibuat menggunakan bahasa Pemrograman HTML, CSS, PHP, jQuery, Javascript serta database MySQL. Aplikasi Sistem Informasi Geografis Wisata dengan memanfaatkan teknologi informasi ini, memudahkan Dinas Pariwisata Kota Ternate menyediakan informasi kepada wisatawan, sehingga para wisatawan dapat mengakses informasi objek wisata bahari dimana saja.
\end{abstract}

Kata kunci: Sistem Informasi, Geografis, Wisata Bahari.

\begin{abstract}
Tourism is one of the leading sectors in the development of national income, to increase absorption of labor and the country's foreign exchange contributor. The purpose of this research is to design a geographic information system on Government tourism office in Ternate city, Methods of analysis and systems development using structured models, as well as its development using sequential linear methods (Waterfall), The system is designed with the tool Flowchart, DFD, ERD and created using programming languages HTML, CSS, PHP, jQuery, Javascript and MySQL database, Application of geographic information system of Tourism by leveraging this information technology, Government tourism office makes it easy to provide information to travelers, so the tourists can access information the maritime sights anywhere.
\end{abstract}

Keywords: Information System, Geographic, Marine Tourism

\section{PENDAHULUAN}

Pariwisata merupakan salah satu sektor unggulan dalam pembangunan untuk meningkatkan pendapatan nasional, penyerap tenaga kerja, dan penyumbang devisa negara. Karena itu pemerintah daerah diharapkan dapat memanfaatkan peluang tersebut, terutama mengoptimalkan potensi sumber daya alam dan keanekaragaman budaya dan tradisi

Sistem informasi geografis pariwisata, berisi tentang informasi dan penjelasan mengenai objek wasiata, sarana transportasi, akomodasi, lembaga keuangan, biro perjalanan, dan sebagainya mulai marak dibangun oleh para stakeholders khususnya di Indonesia. Oleh karena itu diperlukan alat bantu untuk menetahui objek-objek wisata, baik yang sudah dikenal maupun yang belum dikenal.

Namun demikian, objek wisata di Kota Ternate masih kurang dikenal oleh wisatawan dari dalam dan terutama dari luar negeri, sehingga jarang mengunjungi objek wisata di Kota Ternate.Salah satu faktor yang mempengaruhi yaitu masih minimnya pemanfaatan teknologi informasi.Sementara 
penggunaan atau pemanfaatak teknologi informasi untuk pariwisata telah menjadi kecenderungan, tidak hanya pada sejumlah tempat wisata sejumlah daerah di Indonesia. Melainkan pula, terutama di negara-negara maju, untuk menarik minat para wisatawan.

Selain itu, dengan Undang-undang Nomor 10 Tahun 2009 tentang Kepariwisataan, Pemerintah Kota Ternate diharpkan dapat meningkatkan pembangunan pariwisata, meningkatkan kemakmuran dan kesejahteraan masyarakat. Oleh karena itu, Dinas Pariwisata Kota Ternate memiliki kewajiban mempertanggungjawabkan tugas dan fungsinya, melaksanakan kewenangan otonomi daerah dalam rangka pelaksanaan tugas desentralisasi di bidang pariwisata. (Fadhly, et al., 2013).

Kota Ternate merupakan salah satu dari 10 Kabupaten/Kota di Provinsi Maluku Utara yang memiliki banyak objek wisata, baik wisata sejarah, wisata alam, maupun wisata bahari. Wisata sejarah seperti Kedaton Kesultanan Ternate, bentengbenteng peninggalan bangsa kolonial Spanyol, Belanda, dan Portugis. Sedangkan wisata alam seperti Danau Tolire Besar dan Tolore Kecil. Adapun wisata bahari, diantaranya pantai Sulamadaha, Jikomalamo, dan pantai Kastela yang berdampingan dengan Benteng Nosra Senhora del Rosario

\section{Rumusan Masalah}

Berdasarkan latar belakang tersebut, maka masalah yang dirumuskan dalam penilitian ini adalah Bagaimana Merancang Sistem Informasi Geografis Objek Wisata Bahari Pada Dinas Pariwisata Kota Ternate.

\section{Tujuan Penilitian.}

Adapun tujuan penilitian adalah merancang sistem informasi geografis objek wisata bahari pada Dinas Pariwisata Kota Ternate.

\section{Manfaat Penilitian}

Penelitian ini diharapkan dapat memberi manfaat antara lain:

1. Memudahkan Dinas Pariwisata Kota Ternate menyediakan informasi kepada wisatawan.

2. Memudahkan para wisatawan mengakses informasi objek wisata pantai Sulamadaha, Jikomalamo dan pantai Kastela di Kota Ternate.

\section{Tinjauan Pustaka}

Dalam penelitian Erna Kharistiani, Eko Aribowo (2013) yang berjudul Sistem Informasi Geografis Pemetaan Potensi SMA/SMK Berbasis Web (Studi Kasus: Kabupaten Kebumen) mengatakan bahwa Dinas Pendidikan kabupaten Kebumen dalam pengelolaan sekolah belum dapat dilakukan secara optimal sehingga hal ini dapat mengakibatkan permasalahan pengelolaan pendidikan. Dinas Pendidikan kabupaten Kebumen telah memiliki website sebagai media informasi yang mampu diakses secara global, namun informasi informasi yang ditampilkan dalam website tersebut bersifat umum, belum mempu menggambarkan secara detail mengenai keaadan suatu SMA/SMK. Untuk itu diperlukan suatu rencana strategis, melalui perencanaan strategis inilah Dinas Pendidikan kabupaten Kebumen secara sistematis dapat mengembangkan suatu sistem manajerial yang efektif dan efisien, yaitu dengan Sistem Informasi Geografis Pemetaan Potensi SMA/SMK berbasis web. Dengan adanya dukungan teknologi SIG yang berbasis web, diharapkan pengguna dapat mengakses melalui media internet, 
sehingga pendistribusian informasi dapat meluas hingga seluruh nusantara, Hasil dari penelitian ini adalah sebuah aplikasi Sistem Informasi Geografis Pemetaan Potensi SMA/SMK Berbasis Web di kabupaten Kebumen yang dapat memberikan informasi tentang SMA/SMK. Hasil pengujian sistem menunjukkan bahwa sistem informasi ini layak dan dapat dipergunakan.

Penelitian sebelumnya yang dilakukan arisandy ambarita (2017) dengan judul Sistem Informasi Geografis Potensi Tanaman Pangan (Studi Kasus: Kabupaten Halmahera Barat Provinsi Maluku Utara) menguraikan bahwa Dinas Pertanian Halmahera Barat merupakan instansi yang mengelola data dan informasi tentang potensi tanaman pangan yang ada pada Kabupaten Halmahera Barat, yang dalam memberikan data dan informasi potensi tanaman pangan tersebut masih bersifat konvensional kadang informasi data dan lokasi tidak akurat sehingga masyarakat dan para investor yang ingin mengetahui data lokasi dan informasi potensi tanaman pangan tersebut harus turun ke lokasi untuk memastikan potensi tanaman. Untuk itu diperlukan suatu sistem yang dapat mengelola data serta menampilkan informasi potensi tanaman pangan yang ada pada kabupaten Halmahera barat, dengan adanya penelitian ini diharapkan dapat membantu Dinas Pertanian untuk menginformasikan data dan lokasi potensi tanaman pangan kepada pengunjung dan Investor secara cepat dan akurat.

\section{LANDASAN TEORI \\ Pengertian Sistem}

Selanjutnya, McLeod mendefiniskan sistem adalah sekelompok elemen-elemen yang terintegrasi dengan tujuan yang sama untuk mencapai tujuan. Sistem juga merupakan suatu jaringan kerja dari prosedur-prosedur yang saling berhubungan, terkumpul bersama-sama untuk melakukan suatu kegiatan atau untuk tujuan tertentu (Yakub, 2012).

Berdasarkan defenisi tersebut maka dapat disimpulkan, sistem merupakan kumpulan dari beberapa himpunan elemenelemen yang saling berinteraksi, memiliki keterkaitan dan saling bekerja sama serta membentuk suatu kesatuan untuk mencapai suatu tujuan atau sasaran tertentu.

\section{Karakteristik Sistem}

Jogiyanto (2013) mengatakan bahwa suatu sistem mempunyai karakterisktik atau sifat-sifat tertentu, yaitu mempunyai komponen-komponen (components), batasan sistem (boundary), lingkungan luar sistem (environments), penghubung (interface), masukan (input), keluaran (output), pengolah (process), dan sasaran (objectives).

\section{Pengertian Informasi}

Menurut Hartono (2013) informasi pada dasarnya adalah sehimpunan data yang telah diolah menjadi suatu yang memiliki arti dan kegunaan yang lebih luas. Kualitas informasi (quality of information) harus dapat memenuhi beberapa yaitu : akurat, relevan dan tepat waktu.

\section{Pengertian Sistem Informasi}

Menurut O'Brian, sistem informasi (information system) merupakan kombinasi teratur dari orang-orang, perangkat keras, perangkat lunak, jaringan komunikasi, dan sumber daya data yang mengumpulkan, mengubah, menyebarkan informasi dalam sebuah organisasi. (Yakub, 2012).

\section{Pengertian Sistem Informasi Geografis.}

Pada umumnya sistem informasi geografis (geographic information system, 
$G I S$ ) adalah system informasi khusus yang mengelola data yang memiliki informasi spasial. GIS juga merupakan sejenis perangkat lunak yang dapat digunakan untuk memasukkan, menyimpan, manipulasi, menampilkan, dan keluaran informasi geografis (Ambarita, Umagapi, 2017).

\section{Kemampuan Sistem Informasi Geografis}

Kemampuan system informasi geografis (SIG/GIS) mencakup kemampuan untuk menampilkan, mencetak dan memanipulasi berbagai lapisan data termasuk gambar foto udara, informasi keselamatan demografi dan publik, kepemilikan property, pajak, penggunaan lahan, dan informasi zonasi, lokasi utilitas, jalan, fitur alam, topografi, dan banyak fitur buatan manusia dan lingkungan antara lain :

1. Memasukkan dan mengumpulkan data geografis Mengintegrasikan data geografis (spasial dan atribut)

2. Memeriksa dan meng-update (mengedit) data geografis spasial dan atribut

3. Menyimpan dan memanggil kembali data geografis (spasial dan atribut)

4. Mengolah data geografis (spasial dan atribut)

5. Menghasilkan keluaran (output) data geografis dalam (chart) laporan (report) dan lainnya baik dalam bentuk hardcopy maupun soft copy.

\section{Pengertian Peta}

Menurut Badan Koordinasi Survei dan Pemetaan Nasional (Bakorsultana) tahun 2005, peta merupakan wahana bagi penyimpanan dan penyajian data kondisi lingkungan, sumber informasi bagi para perencana dan pengambil keputusan pada tahapan dan tingkatan pembangunan. Menurut Wikantika (2008) peta merupakan gambaran permukaan bumi pada bidang datar dengan skala tertentu melalui suatu system proyeksi (Umagapi, 2017).

\section{Pengertian Pariwisata}

Menurut Sinaga (2012) pariwisata merupakan suatu perjalanan yang terencana, yang dilakukan secara individu maupun kelompok dari satu tempat ke tempat lain dengan tujuan untuk mendapatkan suatu bentuk kepuasan dan kesenangan semata.

\section{Pengertian Analisis Sistem}

Menurut Yakub (2012) Analisa sistem dapat diartikan sebagai suatu proses untuk memahami sistem yang ada, dengan menganalisa jabatan dan uraian tugas (business users), proses bisnis (business prosess), ketentuan atau aturan (business rule), masalah dan mencari solusinya (business problem and business soulution), dan rencana-rencana perusahaan (business plan).

\section{Pengertian DFD ( Data flow Diagram )}

Sutabri (2012) Data Flow Diagram adalah suatu network yang menggambarkan suatu system automa atau komputerisasi, manualisasi, atau gabungan dari keduanya, yang penggambaranya disusun dalam bentuk kumpulan komponen sitem yang saling berhubungan sesuai aturan mainnya.

Keuntungan penggunaan DFD adalah memungkinkan untuk menggambarkan sistem dari level yang paling tinggi kemudian menguraikannya menjadi level yang lebih rendah (dekomposisi). Sedangkan kekurangan penggunaan DFD adalah tidak menunjukkan proses pengulangan (looping), proses keputusan dan proses perhitungan.

\section{Rancangan Input}

Rancangan Input merupakan jembatan yang menghubungkan sistem informasi dengan dana yang dimiliki oleh USER dan 
tergantung apakah sistem tersebut Online / Batch.

Tujuan Dari Rancangan Input:

1. Mengontrol Jumlah Data Input

Proses penyiapan dan pemasukkan data sangat tergantung pada manusia, dengan mengurangi kuantitas kebutuhan data, maka akan mengurangi biaya.

2. Menghinari Kesalahan Data

Kesalahan data, dapat dikurangi dengan rancangan input yang baik, dengan teknik validasi (program komputer)

3. Menghindari Keterlambatan Proses Keterlambatan proses biasanya disebabkan oleh pemasukkan data yang bersifat menunggu (Bottle Neck), kita harus menghindarinya.

4. Merancang Pengolahan Yang Sederhana Rancangan sistem yang baik, harus sesuai dengan orang yang mengoperasikannya dan mudah dipahami (user friendly) tanpa melupakan aspek kontroling data.

5. Menentukan Kebutuhan Input Sistem Baru Bentuk input yang akan dirancang dapat ditentukan dari data flow diagram (DFD) sistem baru yang telah dibuat dengan melihat dataflow yang terjadi dari satu proses ke proses lainnya.

6. Menentukan Parameter Dokumen Input Setelah bentuk output dirancang, maka selanjutnya menentukkan PARAMETER dari dokumen INPUT tersebut, (Fungsi, Sumber, Tujuan, Frekuensi, Kondisi, Media dan Bentuk)

\section{ERD (Entity Relationship Diagram)}

Menurut Brady dan Loonam (2010), dalam bahasa indonesia bahwa Entity Relationship diagram (ERD) merupakan teknik yang digunakan untuk memodelkan kebutuhan data dari suatu organisasi, biasanya oleh System Analys dalam tahap analisis persyaratan proyek pengembangan system. Sementara seolah-olah teknik diagram atau alat peraga memberikan dasar untuk desain database relasional

\section{PHP}

PHP adalah singkatan dari "PHP: Hypertext Prepocessor", yaitu bahasa pemrograman yang digunakan secara luas untuk penanganan pembuatan dan pengembangan sebuah situs web dan bisa digunakan bersamaan dengan HTML. PHP diciptakan oleh Rasmus Lerdorf pertama kali tahun 1994. Pada awalnya PHP adalah singkatan dari "Personal Home Page Tools". Selanjutnya diganti menjadi FI ("Forms Interpreter"). Sejak versi 3.0, nama bahasa ini diubah menjadi "PHP: Hypertext Prepocessor" dengan singkatannya "PHP". PHP versi terbaru adalah versi ke-5. Berdasarkan survey Netcraft pada bulan Desember 1999, lebih dari sejuta site menggunakan PHP, di antaranya adalah NASA, Mitsubishi, dan RedHat.

\section{MySQL}

MySQL adalah sebuah perangkat lunak sistem manajemen basis data SQL (database management system) atau DBMS yang multithread, multiuser,dengan sekitar 6 juta instalasi di seluruh dunia. MySQL AB membuat MySQL tersedia sebagai perangkat lunak gratis dibawah lisensi GNU General Public License (GPL), tetapi mereka juga menjual dibawah lisensi komersial untuk kasus-kasus dimana penggunaannya tidak cocok dengan penggunaan GPL

\section{Xampp}

Pengertian XAMPP adalah perangkat lunak (free software) bebas, yang mendukung untuk banyak sistem operasi, yang merupakan kompilasi dari beberapa 
program. Fungsi XAMPP sendiri adalah sebagai server yang berdiri sendiri (localhost), yang terdiri beberapa program antara lain: Apache HTTP Server, MySQL database, dan penerjemah bahasa yang ditulis dengan bahasa pemrograman PHP danPerl. Nama XAMPP sendiri merupakan singkatan dari $\mathrm{X}$ (empat sistem operasi apapun), Apache, MySQL, PHP dan Perl. Program ini tersedia dalam GNU General Public License dan bebas, merupakan web server yang mudah untuk digunakan yang dapat menampilkan halaman web yang dinamis.

\section{METODE PENELITIAN}

\section{Lokasi dan Waktu Penilitian}

Penelitian dilakukan pada Dinas Pariwisata Kota Ternate. Waktu penelitian akan dilakukan selama dua bulan.

\section{Metode Pengumpulan Data}

Metode pengumpulan data yang digunakan dalam penelitian ini adalah dokumentasi dan wawancara.

\section{Dokumentasi}

Dokumentasi, yaitu mempelajari dokumen yang berkaitan dengan seluruh data yang diperlukan dalam penelitian. Dokumentasi dari asal kata dokumen yang artinya barang-barang tertulis. Di dalam melaksanakan metode dokumentasi, peneliti menyelidiki benda-benda tertulis yang relevan dengan kepentingan peneliti (Sjidmo, 2012).

\section{Wawancara}

Wawancara menurut Nazir (2015) adalah proses memperoleh keterangan untuk tujuan penelitian dengan cara tanya jawab antara si penanya dengan si penjawab.

\section{Studi Kepustakaan}

Dengan mencari dan mengumpulkan data yang diperlukan dari berbagai buku-buku, catatan-catatan, dan gambar-gambar yang menunjang penyusunan laporan tugas akhir ini.

\section{Alur Penelitian}

Dalam melakukan penelitian tentunya memiliki alur atau kerangka penelitiann yang mana. Alur penelitian tersebut dapat memudahkan peneliti dalam melakukan penelitian. Adapun kerangka penelitian ini adalah sebagai berikut :

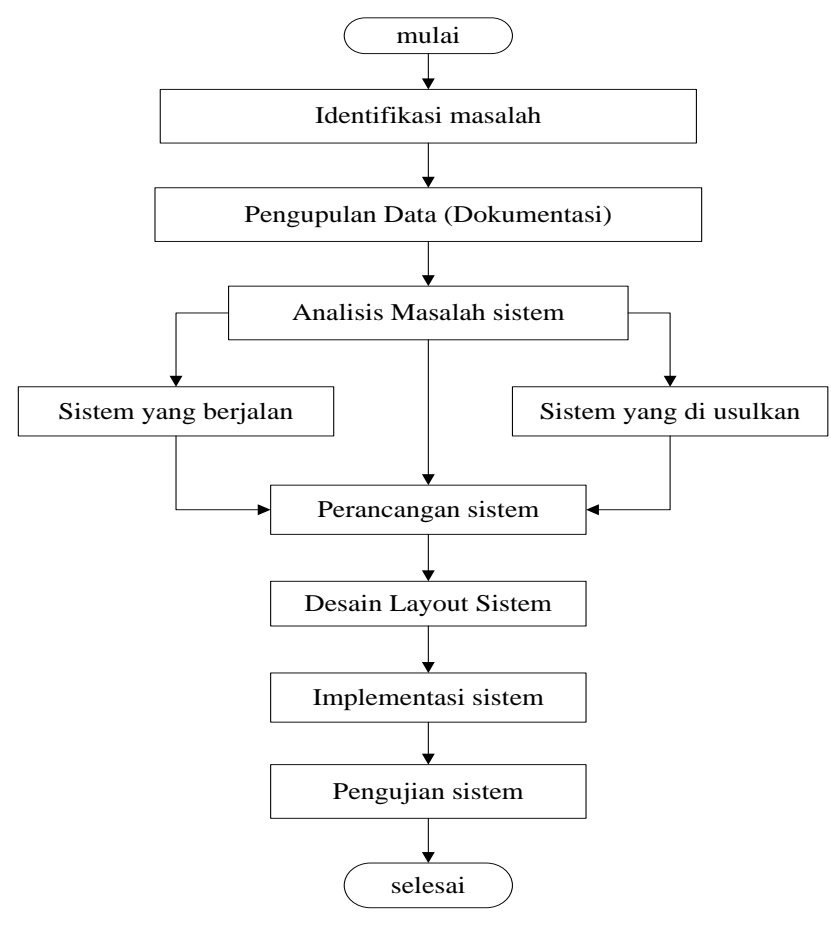

Gambar 1. Alur Penelitian

\section{ANALISIS DAN PERANCANGAN}

Sistem yang sedang berjalan di Sistem Informasi Geografis Wisata Bahari Pada Dinas Pariwisata Kota Ternate, yaitu penympanan data masih bersifat manual. Selanjutnya data-data tersebut disimpan dalam file dokumen arsip. Sedangkan staf pelayanan hanya bisa mengimput data maupun memproses data berupa infromasi pariwisata. Adapun sistem sedang berjalan 
di Sistem Informasi Geografis Wisata Bahari Pada Dinas Pariwisata Kota Ternate diapat dilihat pada gambar berikut;

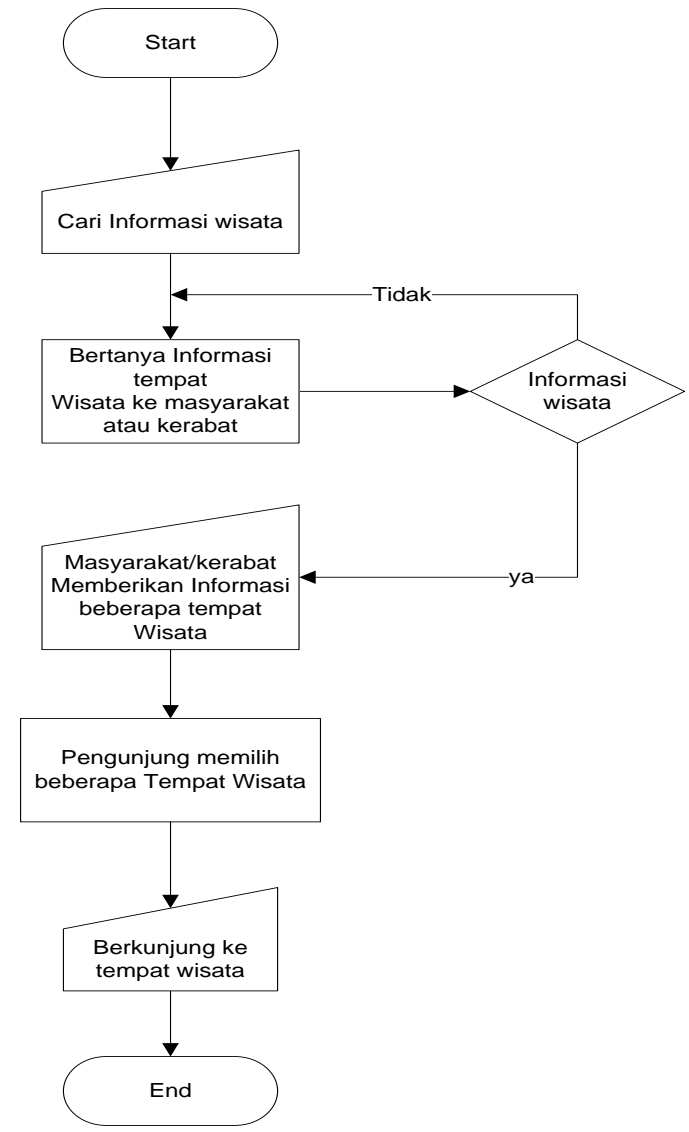

Gambar 2. Flowchart Sistem yang berjalan

\section{Analisis Sistem Yang Diusulkan}

Analisis sistem yang diusulkan merupakan tahapan analisa sistem yang baru yang sudah dianalisa sebelumnya. Dari permasalahan yang sudah teridentifikasi pada sistem yang sedang berjalan maka peneliti mengusulkan sebuah sistem yang di harapkan akan memudahkan Dinas Pariwisata Kota Ternate dalam mengidentifikasi jumlah pengunjung pariwisata baik lokal, nasional maupun manca negara. Sistem yang di usulkan adalah sebagai berikut:

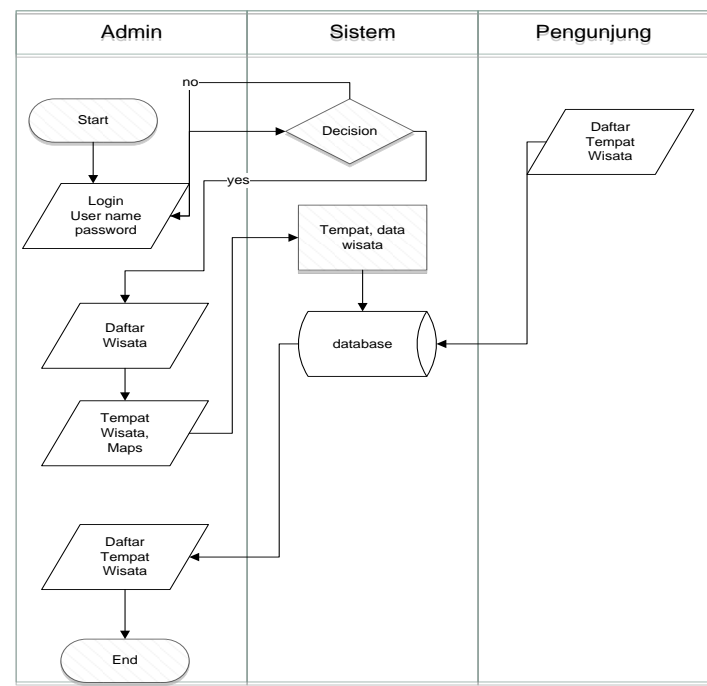

Gambar 3. Sistem yang diusulkan

\section{Diagram Konteks}

Diagram konteks merupakan alat bantu dalam perancangan global bagi program aplikasi yang dibuat. Tujuannya adalah untuk mencerminkan keadaan sistem yang akan dibangun secara umum.

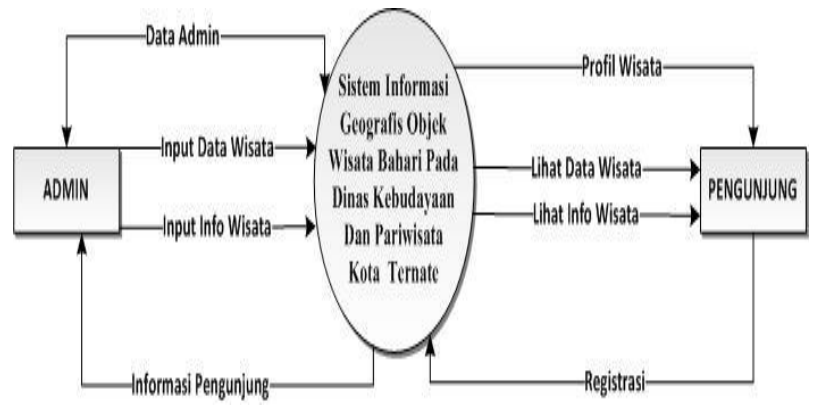

Gambar 4. Diagram Context

\section{Diagram Flow Data (DFD Level 1)}

Data Flow Diagram (DFD) digunakan untuk menganalisa sistem yang telah ada atau sistem baru yang akan dikembangkan secara logika tanpa mempertimbangkan lingkungan fisik dimana data tersebut mengalir atau lingkungan fisik dimana data tersebut disimpan. Berikut ini adalah DFD yang akan digunakan dalam proses pembuatan Sistem Informasi Geografis Wisata Bahari pada Dinas Pariwisata Kota Ternate, Berikut adalah ambar Diagram 


\section{Entity Relationship Diagram (ERD) Notasi}

Entity Relationship Diagram Sistem Informasi Geografis Objek Wisata Bahari Pada Dinas Pariwisata Kota Ternate, dapat di lihat pada gambar berikut:

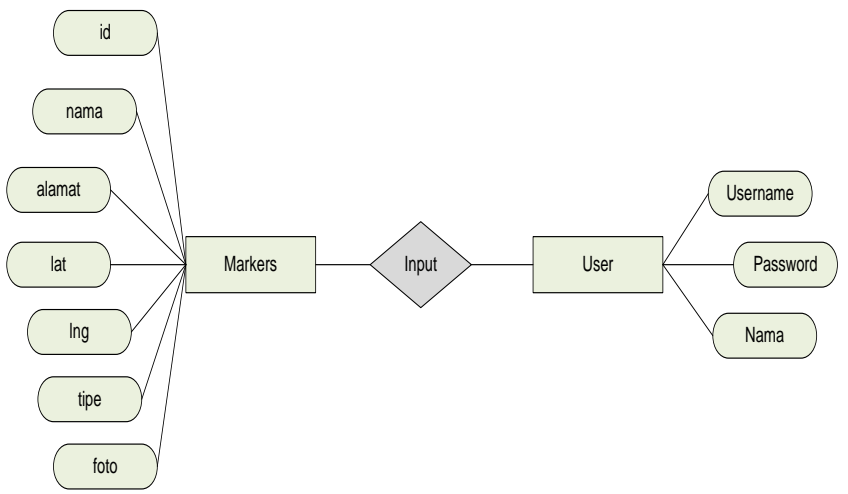

Gambar 5. Entity Relationship Diagram

\section{Perancangan Database dan Tabel}

Perancangan basis data merupakan langkah untuk menentukan basis data yang diharapkan dapat mewakili seluruh kebutuhan pengguna.

1. Entitas, merupakan objek atau kejadian yang mewakili sesuatu yang nyata. Pada model relational, entitas akan menjadi table.

2. Atribut, adalah item data yang menjadi bagian dari suatu entitas atau yang mendeskripsikan karakteristik dari entitas.

3. Record, adalah kumpulan elemenelemen yang saling berkaitan menginformasikan suatu entitas secara lengkap. Misalnya informasi nama , alamat dll.

4. Data value (nilai atau isi data), adalah data aktual atau informasi yang disimpan pada tiap data elemen atau atribut.

5. File, adalah kompulan record - record sejenis yang mempunyai panjang elemen yang sama.

6. Hubungan, adalah kaitan dengan duat entitas.
7. Kunci Primer (primary key), adalah kunci kadidat ang dipilih sebagai kunci utama untuk mengidentifikasikan barisan dalam table.

Kunci Tamu ( Foreign Key ), adalah sebarangan atribut yang menunjuk ke kunci primer pada tabel lain.

\section{Tabel Markers}

Tabel Markers digunakan untuk menyimpan data yang berhubungan dengan Id Markers. Spesifikasi dari tabel Markers adalah sebagai berikut :

Tabel 1. Tabel Markers

\begin{tabular}{|l|c|c|c|}
\hline Field Name & Data Type & Size & Primary Key \\
\hline$\underline{\text { id }}$ & id int & 11 & Yes \\
$\underline{\text { nama }}$ & varchar & 60 & No \\
$\underline{\text { alamat }}$ & varchar & 80 & No \\
$\underline{\text { at }}$ & varchar & 50 & No \\
ing & varchar & 50 & No \\
tipe & varchar & 30 & No \\
foto & varchar & 100 & No \\
\hline
\end{tabular}

\section{Tabel User}

Tabel User digunakan untuk menyimpan data yang berhubungan dengan User. Spesifikasi dari tabel User adalah sebagai berikut :

Tabel 2. Tabel User

\begin{tabular}{|l|c|c|c|}
\hline Field & Data Type & Size & Primary Key \\
\hline Username & Varchart & 20 & Yes \\
Password & Varchart & 20 & No \\
Nama & Varchart & 50 & No \\
\hline
\end{tabular}

\section{Relasi Tabel}

Relasi tabel (Relation) adalah hubungan antara sebuah tabel dengan beberapa tabel yang lainnya. Hubungan ini menunjukkan relasi antara tabel sehingga membentuk suatu jaringan data pada sistem informasi. 


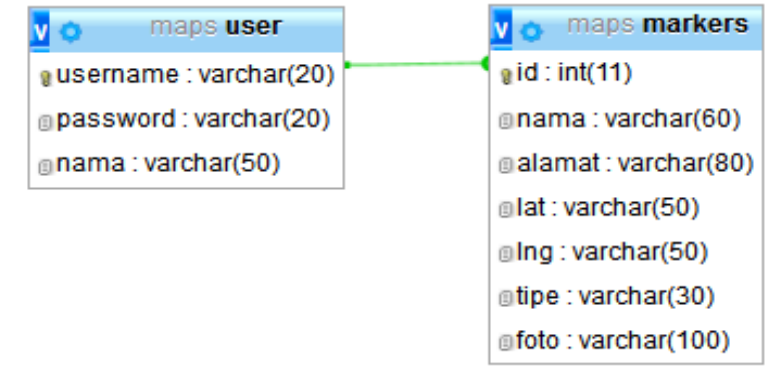

Gambar 6. Relation Tabel

\section{Form Data Daftar Objek Wisata}

Halaman layout Data Daftar Objek Wisata yang di input oleh admin tentang data objek wisata maka akan di tampilkan pada halaman pengunjung.

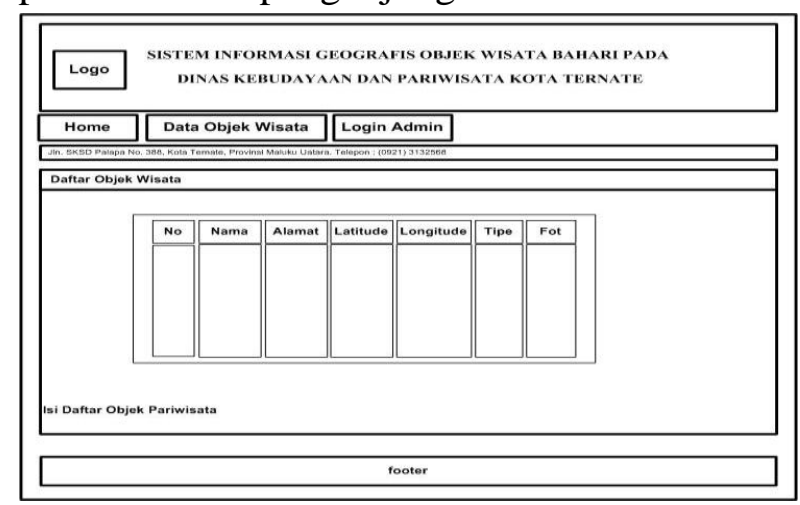

Gambar 7. Daftar objek wisata

\section{Form Input Data Objek Wisata}

Tampilan layout untuk menginput data Objek Wisata dan di simpan ke database yang nantinya di tampilkan pada tabel dan laporan data Objek Wisata setelah mengklik tombol simpan. Berikut tampilan layout input data objek wisata

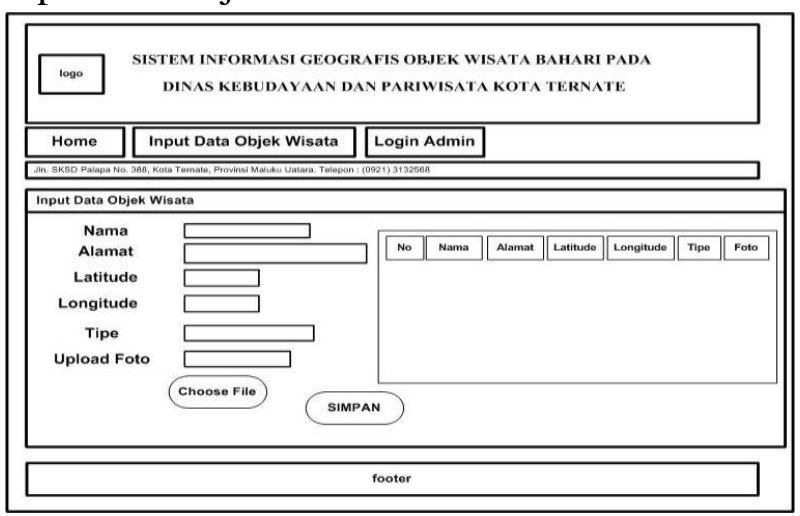

Gambar 8. Tampilan data objek wisata

\section{Form Laporan Daftar Objek Wisata}

Pada gambar di bawah ini merupakan tampilan layout laporan rekapitulasi daftar penginputan data Objek Wisata. Dalam laporan tersebut dapat dilakukan operasi data dengan melihat data dengan cara mengklik tombol hapus untuk menghapus data yang sudah tersimpan pada tabel data daftar objek wisata.

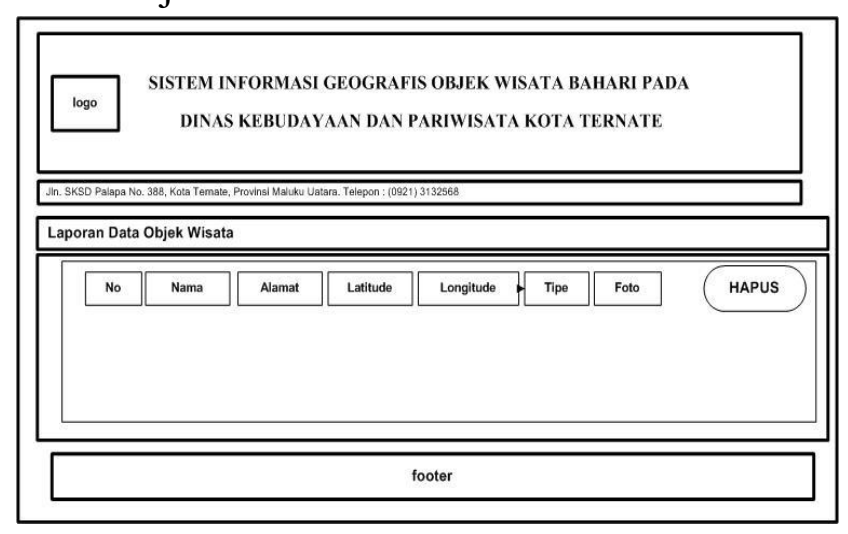

Gambar 9. Laporan Data Objek Wisata

\section{IMPLEMENTASI DAN PEMBAHASAN}

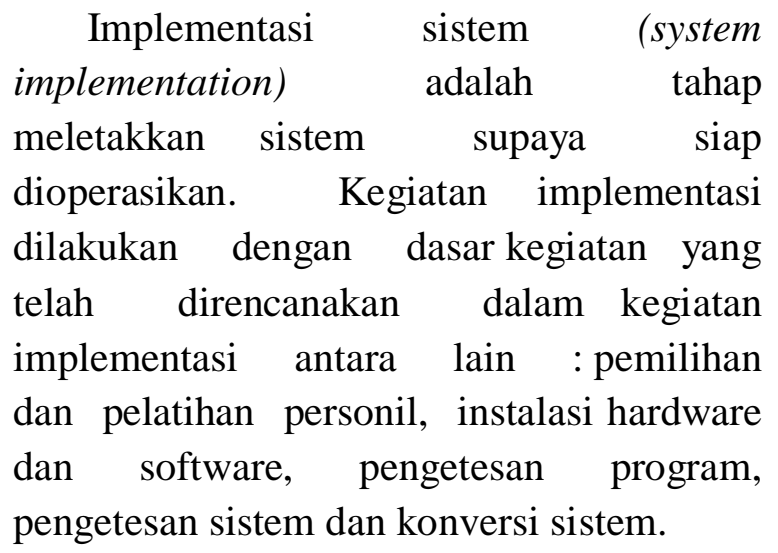

\section{Perangkat Keras}

Perangkat keras yang digunakan dalam penelitian ini berupa perangkat keras(hardware) dengan spesifikasi yaitu:

1. Laptop Axioo-PC

2. Procesor Intel(R) Atom TM CPU N570 @ $1.666 \mathrm{GHz}$

3. Ram 2, $00 \mathrm{~GB}$

4. Hardisk $160 \mathrm{~GB}$

5. Printer Canon ip2870S 


\section{Perangkat Lunak}

Alat yang digunanakan dalam penelitan ini berupa perangkat lunak (software).

1. Windows7 Ultimate sebagai system operasi

2. Ms. Access 2007 sebagai pengelola database

3. Program web : Xamp, Mysql, Php dan Html.

4. Microsoft Visio 2007

\section{Form Login Administrator}

Tampilan form login. Orang yang berhak melakukan akses pada halaman ini harus login terlebih dahulu dengan memasukan username dan password. Pengguna yang berhak melakukan proses login ini adalah administrator.

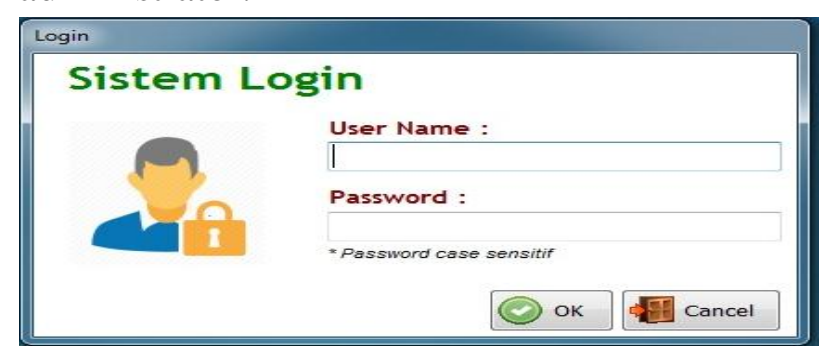

Gambar 10. Gambar Form Login

\section{Form Menu Utama}

Tampilan ini berisi menu-menu utama yang di guanakan untuk menampilkan data daftar objek wisata yang sudah di input oleh admin.

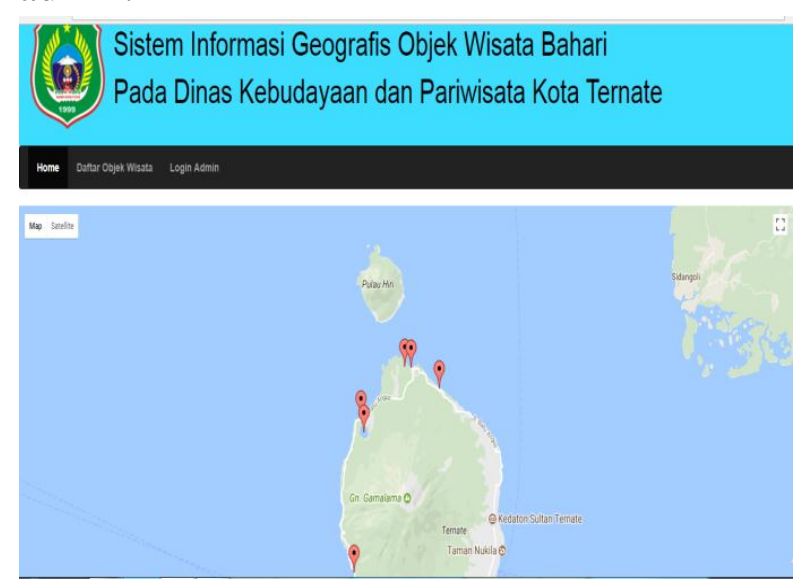

Gambar 11. Gambar Form Menu Utama

\section{Form Input Data Objek Wisata}

Tampilan form untuk menginput data Objek Wisata dan di simpan ke database yang nantinya di tampilkan pada tabel laporan data Objek Wisata

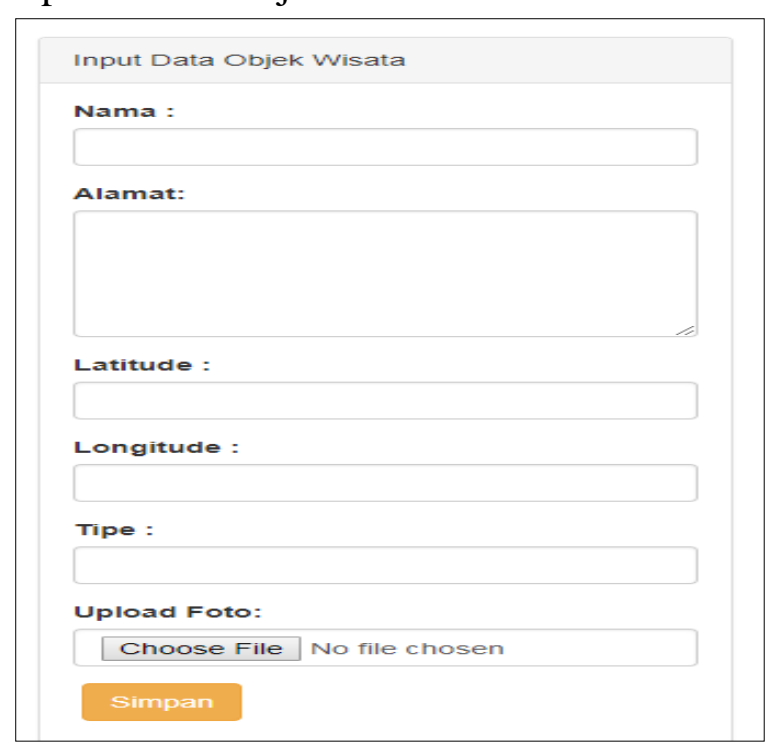

Gambar 12. Form Data Objek Wisata

\section{Form Laporan Daftar Objek Wisata}

Halaman form Data Daftar Objek Wisata yang di input oleh admin tentang data objek wisata maka akan di tampilkan pada halaman pengunjung.

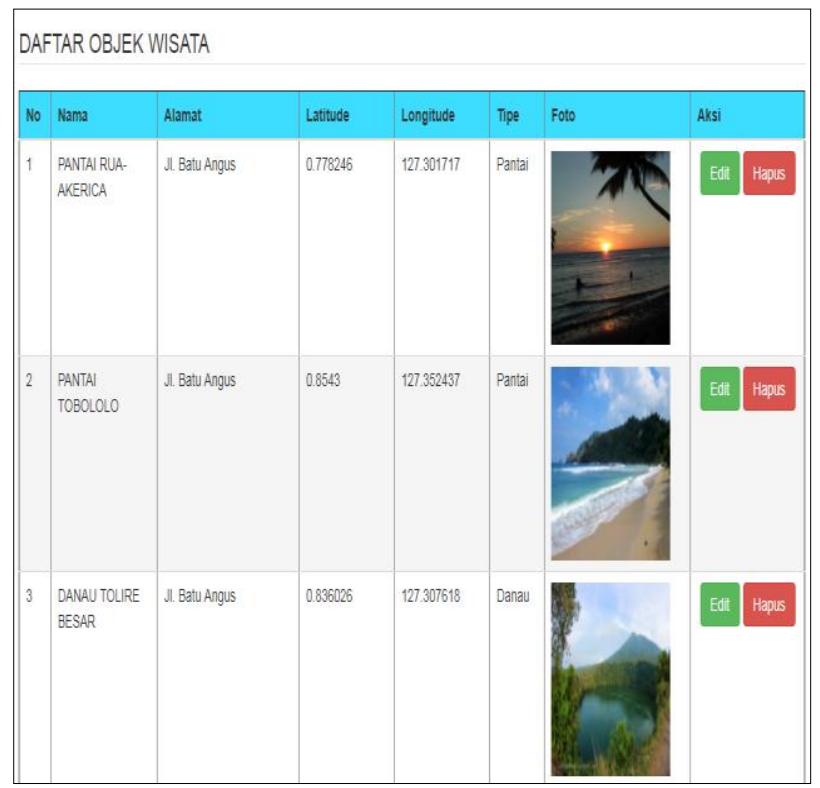

Gambar 13. Laporan Daftar Objek Wisata

KESIMPULAN 
Berdasarkan hasil implementasi dan pengujian maka dapat disimpulkan sebagai berikut:

1. Website ini dapat membantu mempromosikan objek wisata bahari kota ternate kepada seluruh masyarakat baik lokal maupun nasional.

2. Website ini memberikan kemudahan kepada masyarakat dalam mencari informasi mengenai objek wisata kota ternate.

3. Website ini memberikan kemudahan dalam menginformasikan event-event yang ada di Dinas Pariwisata Kota Ternate.

\section{Saran}

Berdasarkan kesimpulan diatas maka dalam penelitian ini untuk mencapai kesempurnaan dari penelitian maka dapat disarankan sebagai berikut:

1. Pembangunan website ini masih bisa dibuat semenarik mungkin dan dikembangkan lebih lanjut terutama dalam tampilan sistemnya.

2. Dari segi yang disajikan mungkin belum sepenuhnya sempurna, oleh karena itu, ada baiknya dengan menambah beberapa informasi yang lebih lengkap.

3. Agar website ini kelihatan cantik, disarankan untuk menambah sekaligus diperbanyak animasi, dengan tujuan agar pengunjung dalam mengakses website ini tidak cepat bosan.

\section{DAFTAR PUSTAKA}

Darmawijaya, et al., 2014. Pasir, Batu dan Etos Budaya: Catatan dari Maluku Utara. LeutikaPrio. Yogyakarta.

Fadhly, Moh Yushar, et al.,2012. Permasalahan Pengembangan Objek Bersejarah dalam Menunjang Wisata di Kota Ternate.
Indrajit, Prof. Dr. Eko Richardus, 2001. Pengantar Konsep Dasar Manajemen Sistem dan Teknologi Informasi. APTIKOM. Yogyakarta.

Jogiyanto, 2013. Analisis \& Desain Sistem Informasi, Pendekatan Terstruktur, Teori Dan Praktik Aplikasi Bisnis. Andi Offset. Yogyakarta.

Ladjamudin, 2013. Analisis dan Desain Sistem Informasi. Graha Ilmu. Yogyakarta.

Muharto \& A. Ambarita (2016). Metode Penelitian Sistem Informasi: Mengatasi Kesulitan Mahasiswa Dalam Menyusun Proposal Penelitian. Deepublish. Yogyakarta.

Prahasta, Eddy, 2012. Sistem Informasi Geografis (Konsep Dasar Perspektif Geodesi \& Geomatika). Informatika. Bandung.

Sutarman, 2012. Pengantar Teknologi Informasi. Bumi Aksara. Jakarta

Tata Sutabri. 2012. Analisis Sistem Informasi. Andi. Yogyakarta

Yakub, 2012, Pengantar Sistem Informasi, Graha Ilmu, Yogyakarta

Bakosurtanal, 2005. Definisi Peta Digital. http://nationalinks.blogspot.com/2009/03 /d finisi-peta.html.[5 Maret 2018].

Arisandy Ambarita. Sistem Informasi Geografis Potensi Tanaman Pangan (Studi Kasus: Kabupaten Halmahera Barat Provinsi Maluku Utara). IJNS Indonesian Journal on Networking and Security. Volume 6 No 1, Tahun 2016, ISSN : 2302-5700 (Print) - 2354-6654 (Online)

Darman Umagapi, 2016. Sistem Informasi Geografis Tempat Wisata, Studi Kasus Kota Ternate Provinsi Maluku Utara. Jurnal BianglalaInformatika, Vol 4 No 2 Oktober, Tahun 2016, ISSN: 23388145 (Print), 2338-9761 (Online)

Erna Kharistiani, Eko Aribowo, Sistem Informasi Geografis Pemetaan Potensi SMA/SMK Berbasis Web (Studi Kasus : Kabupaten Kebumen), Jurnal Sarjana Teknik Informatika Volume 1 Nomor 1, Juni, Tahun 2013 e-ISSN: 2338-5197 